\title{
Model Kepemimpinan Transformasinal Kepala Sekolah SMK Negeri
}

\author{
Sitti Hartinah \\ Email: shartinah_ups@yahoo.co.id
}

\begin{abstract}
Abstrak: Model kepemimpinan transformasional kepala sekolah terbentuk dari berbagai asfek yaitu kompetensi, iklim organisasi sekolah dan etos kerja. Permasalahannya adalah apakah model kepemimpinan transformasional kepala sekolah dikonstruk dari dimensi kompetensi, iklim organisasi sekolah dan etos kerja. Tujuan penelitian ini mencari model kepemimpinan transformasional kepala sekolah di SMKN Tegal. Desain penelitian ini adalah berpendekatan confirmatory factor analysis. Jumlah sampel 200 dipilih secara proportional random sampling. Instrumen menggunakan "questionare"dengan reliability.

Desain penelitian dengan paradigma kuantitatif, menjelaskan hubungan kausal variabel melalui uji hipotesis, dengan pemodelan persamaan structural (SEM). Hasil analisis menemukan kesesuaian model konseptual dengan model teruji bahwa kepemimpinan transformasional kepala sekolah dipengaruhi secara signifikan oleh; kompetensi kepala sekolah $(24,5 \%)$; iklim organisasi sekolah $(29,4 \%)$; etos kerja $(28,1 \%)$; Model faktor kompetensi kepala sekolah, iklim organisasi sekolah, dan etos kerja secara simultan berkontribusi terhadap kepemimpinan transformasional kepala sekolah sebesar (85,6\%). Implikasinya jika ingin meningkatkan kompetensi kepala sekolah, iklim organisasi sekolah dan etos kerja maka perlu dikembangkan model kepemimpinan transformasional kepala sekolah dalam model yang teruji ini. Berdasarkan temuan, disarankan agar kepala sekolah, memiliki keterampilan manajerial, memperbaiki iklim organisasi sekolah dan peningkatan etos kerja kepala secara maksimal
\end{abstract}

Kata Kunci: kompetensi kepala sekolah, iklim organisasi sekolah, etos kerja dan kepemimpinan tarnsformasional kepala sekolah

Abstrach: The ground reasons of this study is in what way transformational leadership is suitable to increase education quality in vocational high school. Meanwhile, the specific problems are as follows: (1) do principals' competency variables consisting of personality, management, entrepreneurship, supervision, and social competency dimensions directly contribute and significantly influence to the principals transformational leadership?; (2) do school organizational conditions to directly contribute and significantly influence to the principals transformational leadership?; (3) do work ethics contribute and significantly influence to the principals transformasional leadership?; and (4) in what way is principals transformational leadership model suitable to increase education quality of vocational high schools' principals.

This research design was confirmatory factor analysis approach was Structural Equation Model (SEM). The result of this study shows that school principal competence contributes $(24,5 \%)$ and significantly influences to school principal leadership, school organizational conditions $(29,4 \%)$ and significantly influences to principal transformational leadership, meanwhile the determinant factors including school principal competence, school organizational conditions and work ethics contribute $(0,856 \%)$ and significantly influence. A suitable principal transformational leadership model to develop vocational high school quality is through school organizational conditions; work ethics; principal competence rights.

Based on these findings, a school principal should be guided by the main principle when he performs his work, in order to have abilities and skills in managing his school effevtively; a principal should have work-culture to achieve an effective school organizational conditions; a principal should be able to increase a culture of work ethics for school members by enhancing their presence to always come at school; has commitment to develop his school, educational institutions should arrange the planning of principals 
training about soft skill entrepreneurship in order they have maximal work ethics in increasing the education quality at vocational high school.

Keywords: principal's competency, school organizational condition, hard-earned and principal transformational leadership.

\section{Pendahuluan}

Keberhasilan sekolah dalam melaksanakan segala aspek yang telah direncanakannya perlu didukung oleh kepe-mimpinan kepala sekolah. Kepala sekolah sebagai pemimpin satuan pendidikan merupakan motor penggerak sumber daya sekolah terutama guru dan karyawan sekolah. Sebesar apapun input persekolahan ditambah atau diperbaiki, outputnya tidak akan optimal apabila faktor kepemimpinan kepala sekolah tidak diberikan perhatian yang memadai, tersedianya dana, infrastruktur, fasilitas, dan instrumen pendidikan lainnya kurang dapat didayagunakan secara maksimal, efisien, dan akuntabel tanpa adanya kepemimpinan yang kuat, atau adanya pemimpin yang mampu menggerakkan semua komponen itu.

Kepala sekolah adalah pengelola terdepan yang memuluskan proses dan interaksi positif seluruh input sistem belajar-mengajar. Lebih dari itu, kepala sekolah memainkan peranan penting dalam keseluruhan upaya peningkatan kinerja, baik pada tingkat kelompok maupun organisasi. Kepemimpinan kepala sekolah menempati posisi penting dalam penelaahan manajemen pendidikan. Fungsi dan substansi manajemen pendidikan yang dijalankan oleh kepala sekolah meliputi pengorganisasian sumber daya pendidikan, proses pendidikan, dan pembelajaran. Kepala sekolah berperan pula sebagai katalisator pendidikan yang mendorong setiap kegiatan di sekolah. Krajewsky (1983:178) kepala sekolah merupakan "the key to quality in the school and must be catalyst when its comes to the quality of educational programs". Sekolah bertugas menyelenggarakan proses pendidikan dan proses belajar mengajar untuk mencerdaskan kehidupan bangsa sangat didambakan oleh setiap warga sekolah. Kepala sekolah yang diberi tugas untuk memimpin sekolah, harus bertanggung jawab atas tercapainya tujuan sekolah, dan diharapkan menjadi pemimpin dan inovator, oleh sebab itu, kualitas kepemimpinan kepala sekolah adalah signifikan bagi keberhasilan sekolah.

Sebagai pimpinan, kepala sekolah mempunyai tugas (1) menyusun perencanaan; (2) mengorganisasikan, mengarahkan, mengkoordinasikan, dan mengevalusi kegiatan; (3) menentukan kebijakan dan melakukan pengawasan; (4) mengatur proses belajar mengajar; dan (5) mengatur hubungan sekolah dengan masyarakat dan dunia usaha. Kepala sekolah sebagai pimpinan satuan pendidikan dihadapkan pada tugas yang harus diselesaikan. Nurhadi (2003:54) menegaskan bahwa kepala sekolah sebagai penanggungjawab semua kegiatan administrasi pendidikan sekolah, karena itu kepala sekolah mempunyai kedudukan tertinggi dalam organisasi satuan pendidikan.

Kepala sekolah wajib mengembangkan budaya kualitas, mengemban tugas kepemilikan visi yang sangat kuat terhadap kualitas total bagi institusinya, komitmen yang jelas terhadap proses peningkatan kualitas peserta didik di sekolah menengah kejuruan, secara terus menerus berkomunikasi tentang kualitas pelayanan terhadap seluruh jajaran komponen yang terdapat di SMK, serta unit kerjanya, seluruh kebijakannya berorientasi kepada peningkatan kualitas, transparan, dan proaktif terhadap aspirasi yang berkembang khusus pada pelanggan, menggerakkan staf untuk bekerja lebih dinamis-inovatifproduktif, sanggup melakukan koreksi diri terhadap kebijakannya, memiliki team work yang efektif, dan mampu mengembangkan mutu pendidikan di sekolah.

Salah satu faktor penting yang menentukan tinggi rendahnya mutu pendidikan dan keefektifan sekolah ialah kepemimpinan kepala sekolah. Makna kepemimpinan bukan hanya mengambil inisiatif, tetapi juga mengandung makna kemampuan manajerial, yaitu kemampuan mengatur dan menempatkan sesuatu sesuai dengan tempatnya. Keberhasilan suatu sekolah 
pada hakikatnya terletak pada efisiensi dan efektivitas penampilan seorang kepala sekolah (Sumidjo 2006:349).

Pada masa kini dan masa mendatang, kepemimpinan SMK dituntut memiliki kemampuan berikut: (1) mengidentifikasi diri sebagai agen perubahan; (2) berani dan teguh; (3) memiliki kepercayaan pada orang lain; (4) dapat berperan sebagai value-driven; (5) memiliki sikap pembelajar seumur hidup; (6) mempunyai kemampuan untuk menghadapi kompleksitas, dan ketidak-pastian; dan (7) visioner. (Gaffar 2005:167). Pemimpin yang demikian itu diyakini dapat memposisikan diri dan memfungsikan lembaga yang dipimpinnya dalam hal: (1) pengartikulasian visi masa depan organisasi; (2) penyediaan suatu model yang tepat; (3) pemelihara penerimaan tujuan kelompok; (4) harapan terhadap kinerja yang tinggi; (5) pemberian dukungan individual; dan (6) stimulasi intelektual (Mulyasa, 2006). Lebih lanjut Depdikbud (2009) dalam (Jalal 2008) menegaskan pentingnya kepala sekolah yang memiliki kemampuan profesional yaitu: kepribadian, keahlian dasar, pengalaman, pelatihan dan pengetahuan profesional, serta kompetensi administrasi dan pengawasan. Jalal (2008:5) mengidentifikasi empat masalah pokok pendidikan dalam kerangka otonomi sekolah. Dua masalah di antaranya ialah: (1) kepala sekolah tidak memiliki kewenangan yang cukup dalam mengelola keuangan sekolah yang dipimpinnya; dan (2) kemampuan manajemen kepala sekolah pada umumnya rendah, terutama di sekolah negeri.

Pengangkatan kepala sekolah terlalu menekankan pada pertimbangan urutan jenjang kepangkatan dan mengabaikan factor kemampuan dalam memimpin lembaga. Selanjutnya pemimpin yang bisa membawa perubahan ke arah kebaikan bila dalam diri seorang pemimpin itu minimal terdapat tiga unsur, yakni (1) ada seorang pemimpin yang memimpin, mempengaruhi, dan memberikan bimbingan; (2) ada bawahan yang dikendalikan; dan (3) ada tujuan yang diperjuangkan melalui serangkaian kegiatan. (Anwar 2003: 67) Membawa perubahan yang dimaksud seperti yang dinyatakan Locke (1997) adalah kepemimpinan transformasional sebagai pemimpin yang melibatkan perubahan dalam organisasi. Kepemimpinan ini, sebagai kepe- mimpinan yang membutuhkan tindakan memotivasi para bawahan agar bersedia bekerja demi sasaran "tingkat tinggi" yang dianggap menaruh kepentingan pribadinya pada saat itu (Bass (1985). Sejalan itu, Tjiptono (2009) mengatakan bahwa pemimpin transformasional bisa berhasil mengubah status quo dalam organisasinya dengan cara mempraktikkan perilaku yang sesuai pada setiap tahapan proses.

Hasil pengamatan di SMK Negeri Tegal memberikan gambaran sebagai berikut; $33 \%$ dari responden guru menganggap kompetensi kepala sekolah cukup baik; 40,5\% dari responden guru mempersepsikan iklim organisasi sekolah cukup baik; dan 34,5\% dari responden guru menilai etos kerja cukup baik. Hasil itu mengindikasikan keterkaitan antara kompetensi kepala sekolah, iklim organisasi sekolah, dan etos kerja kepala sekolah dengan kepemimpinan transformasional kepala sekolah. Isu penting sehubungan dengan hasil pengamatan itu adalah kelangkaan model kepemimpinan kepala sekolah yang relevan untuk menjawab persoalan tentang kepala sekolah, misi pendidikan, dan lemahnya relevansi pendidikan SMK. Model kepemimpinan itu secara teoretik dikonsepsikan sebagai kepemimpinan transformasional yang bercirikan adanya proses membangun komitmen bersama terhadap organisasi dan memberikan kepercayaan kepada para pengikut untuk mencapai sasaran. Menurut Burn (1978), dalam kepemimpinan transformasional, pemimpin mencoba menimbulkan kesadaran dari para pengikutnya dengan menyerukan cita-cita yang lebih tinggi dan nilai moral.

Latar belakang masalah di atas menjadi alasan yang kuat bagi penulis untuk menemukan model kepemimpinan transformasional kepala sekolah yang dipengaruhi oleh kompetensi kepala sekolah; iklim organisasi sekolah yang tercipta; dan etos kerja kepala sekolah. Dengan demikian, rumusan masalahnya adalah apakah terdapat hubungan antara kompetensi kepala sekolah dengan kepemimpinan transformasional? Apakah iklim organisasi sekolah terdapat hubungan dengan kepemimpinan transformasional serta etos kerja memiliki hubungan terhadap kepemimpinan transformasional kepala sekolah; serta apakah terdapat hubungan antara kompetensi kepala sekolah, iklim organisasi 
sekolah, dan etos kerja secara bersama-sama terhadap kepemimpinan transformasional kepala sekolah di SMK Negeri Tegal

Tujuan kajian ini mengetahui: 1) hubungan kompetensi kepala sekolah dengan kepemimpinannya, 2) hubungan iklim organisasi sekolah dengan kepemimpinannya, 3) hubungan etos kerja terhadap kepemimpinannya, dan 4) mengetahui secara bersama-sama antara variabel kompetensi kepala sekolah, iklim organisasi serta etos kerja terhadap kepemimpinan transformasional kepala sekolah SMK Negeri Tegal.

\section{Kepemimpinan Transformasional}

Penelitian ini difokuskan pada elemen kepemimpinan transformasional kepala sekolah di SMK yang berorientasi pada mutu layanan dan mutu proses dapat meningkatkan kualitas pendidikan di sekolah. Mutu layanan itu berimplikasi pada terciptanya suasana kerja yang kondusif, iklim organisasi sekolah yang nyaman, etos kerja yang tinggi yang berorientasi pada kualitas. Model yang dieksplorasi adalah kepemimpinan transformasional yang dibangun dengan variabel kompetensi kepala sekolah, iklim organisasi sekolah, dan etos kerja.

Kepemimpinan adalah suatu tindakan memotivasi bawahan untuk melaksanakan tugas, dan kepemimpinan merupakan aspek yang paling dominan dalam manajemen suatu organisasi. Kunci kepemimpinan adalah pemimpin, stimulus, motivasi, dan bawahan. Kepemimpinan merupakan kemampuan dan keterampilan seseorang yang menduduki jabatan sebagai pemimpin suatu unit kerja untuk mempengaruhi perilaku bawahnya. Kepemimpinan adalah "the ability and readiness to inspire, guide, direct, or manage other" (Good 1973). Pengaruh model kepemimpinan terhadap bawahan ini seperti yang dinyatakan Bass (1999:21) adalah memberikan inspirasi pengikutnya untuk mengarahkan kepentingan pribadi bagi kebaikan organisasi, mengakui nilai dan filosofi, dan memikirkan masalah dengan cara baru. Pernyataan ini merupakan model kepemimpinan transformasional dikembangka dalam konteks politik dan selanjutnya ke dalam konteks organisasional. Kepemimpinan ini yang dinilai paling tepat terhadap gaya kepemimpinan yang paling efektif. Sejalan itu, Tjiptono (2006) mengatakan bahwa pemimpin transformasional bisa berhasil mengubah status quo dalam organisasinya dengan cara mempraktikkan perilaku yang sesuai pada setiap tahapan proses transformasi.

Pemimpin bergaya transformasional, berkemampuan mengubah perilaku kepemimpinannya yang tradisional dan kurang responsif terhadap pembaharuan menjadi pemimpin yang berkesanggupan mentransformasi jalannya roda organisasi, sesuai dengan perannya sebagai penunjuk arah, tujuan dimasa depan (direct setter), agen perubahan (change agent), negosiator (spokesman), dan sebagai pembina (coach), di dalam bidang pendidikan, seiring dengan upaya pembaharuan yang dilakukan, bentuk kepemimpinan penting untuk diformulasikan. Bass (1985) dan Sillin (1994:421), kepemimpinan transformasional terdiri dari tiga komponen (1) kharisma; (2) kepekaan intelektual; dan (3) stimulasi intelektual. Kepemimpinan transformasional digambarkan sebagai bentuk kepemimpinan yang mampu meningkatkan komitmen staf (Hunt 1991) mengkomunikasikan suatu visi dan implementasinya (Dunphy 1990) memberikan kepuasan dalam bekerja dan mengembangkan fokus yang berorientasi pada klien. Konsep itu, dapat disimpulkan adanya penokohan seorang pemimpin dengan menggunakan elemen kharisma, mampu memberikan ilham, loyalitas dan ketekunan, menanamkan kebanggaan, kesetiaan, serta membangkitkan rasa hormat. Pemimpin yang memiliki ciri, memperlihatkan visi, kemampuan, dan keahliannya serta tindakan yang lebih mendahulukan kepentingan organisasi dan kepentingan orang lain (masyarakat) dari pada kepentingan pribadi. Karena itu, pemimpin karismatis dijadikan suri tauladan, idola, dan model panutan oleh bawahannya. Dengan demikian, menjadi sangat kuat diyakini bahwa kepemimpinan jenis ini memang diperlukan dalam era paskamodernisasi.

Secara teoritis diyakini bahwa gaya kepemimpinan transformasional amat menjanjikan untuk diterapkan pada organisasi pembelajaran seperti di sekolah menengah kejuruan. Hal penting untuk memimpin perjalanan ke masa depan yang dapat dijadikan pijakan bagi kepala sekolah SMK dalam 
mengembangkan sekolahnya, yaitu (1) tidak menunggu, yaitu bahwa kepala sekolah harus proaktif dan meraih kemenangan dini; (2) memiliki karakter yang berbobot, harus memiliki kredibilitas; (3) se-orang kepala sekolah kepalanya ada di awan, sedangkan kakinya ada di bumi, artinya bahwa "di samping kepala sekolah itu harus memiliki kesadaran arah dan visi untuk melihat ke depan, tetapi sekaligus harus dapat mengayomi dan bisa dibanggakan; dan (4) memiliki sistem nilai bersama, artinya bahwa apa yang dikatakan pemimpin harus sesuai dengan harapan pengikutnya. Selain itu, kepala sekolah tidak bisa mengerjakan sendiri, artinya bahwa strategi yang mampu memenangkan dalam memimpin adalah filosofi "kami" dan bukan "aku". Kepala sekolah meninggalkan warisan berupa kehidupan yang dijalani bersama, maka tempalah aturan emas kepemimpinan. Kepemimpinan adalah kepentingan setiap orang, artinya setiap orang otomatis adalah pemimpin.

\section{Kompetensi Kepala Sekolah}

Suatu persyaratan penting bagi keefektifan suatu organisasi atau kesuksesan pemimpin (kepemimpinan) dan manajer (manajemen) dalam mengemban peran, tugas, fungsi, ataupun tanggungjawabnya adalah kompetensi. Boyatzis (1982:89) kompetensi sebagai "kemampuan yang dimiliki seseorang yang nampak pada sikapnya yang sesuai dengan kebutuhan kerja dalam parameter lingkungan organisasi dan memberikan hasil yang diinginkan". Lebih lanjut Sanusi (2001:123) mempertautkan kemampuan kepala sekolah dengan misi profesionalnya terdiri atas (1) kemampuan dalam administrasi sekolah yang meliputi kemampuan tujuan, kemampuan proses dan kemampuan manajerial; serta (2) komitmen dalam administrasi sekolah yang meliputi orientasi ke arah syarat keunggulan profesional, aktif berpartisipasi dalam kegiatan belajar mengajar yang profesional, dan dedikasi terhadap pengembangan konsep yang lengkap tentang the principalship. Kepemimpinan kepala sekolah berkenaan pula dengan pemilikan kompetensi dasar manajerial pada diri pemimpin, berhubungan dengan pengetahuan, metode dan teknik tertentu dalam menyelesaikan tugas.

Kompetensi kepala sekolah adalah kapasitas dari pengetahuan, keterampilan dan sikap yang dimiliki oleh seorang kepala sekolah yang relevan dengan standar kompetensi yang akan dilakukan sehingga mampu melaksanakan pekerjaan yang telah dirancang bagi dirinya baik untuk saat ini maupun pada masa yang akan datang. Kepala sekolah disamping sebagai katalis perubahan juga memiliki visi yang jelas, memiliki gambaran holistik tentang bagaimana organisasi di masa depan ketika semua tujuan sasarannya telah tercapai (Covey 1992); (Peters 1992); dan Sergiovanni (1990) menyatakan bahwa keberhasilan organisasi dalam mencapai tujuan yang berbasis kompetensi tercermin dari tampilan ciri kompetensi yang harus dimilikinya, diidentifikasi dari hubungan interaksional antara perilaku kepemimpinan kepala sekolah dalam melaksanakan fungsi merencanakan, mengorganisasi, memimpin dan mengendalikan sumber daya. Iklim yang kondusif berhubungan dengan etos kerja yang kuat, sebaliknya iklim yang otoriter dan sentralisasi pengambilan keputusan tidak menguntungkan bagi organisasi, sementara tingkah laku guru sangat ditentukan oleh peraturan dan prosedur standar kerja bukan menjurus ke arah produktivitas rendah tetapi menghasilkan sedikit kepuasan dan sikap negatif terhadap organisasi (Burhanudin 2004:102).

Sesuai dengan Peraturan Pemerintah No: 19 Tahun 2005 tentang Standar Nasional Pendidikan, Bab VI Standar Pendidik dan Tenaga Kependidikan pasal 38 Ayat 1 untuk menjadi kepala SMP/MTs/ SMA/ MA/SMK/MAK meliputi (1) berstatus sebagai guru SMP/MTS/SMA/MA/SMK/MAK; (2) memiliki kualifikasi akademik dan kompetensi sebagai agen pembelajaran sesuai ketentuan perundangundangan yang berlaku; (3) memiliki pengalaman mengajar sekurang-kurangnya 5 (lima) tahun di SMP/MTs/SMA/MA/SMK/MAK; dan (4) memiliki kemampuan kepimpinan dan kewirausahaan di bidang pendidikan.

Keputusan Mendiknas No 13 tahun 2007 tentang kompetensi kepala sekolah, dapat diklasifikasikan dengan kompetensi kepribadian, kompetensi manajerial, kompetensi kewirausahaan, kompetensi supervisi serta kompetensi sosial, seperti dibawah ini. Kelima kompetensi ini harus dimiliki oleh kepala sekolah dalam melaksanakan tugasnya sebagai kepala sekolah 
SMK. Kepala sekolah sebagai pemegang kunci keberhasilan dalam pengelenggaraan pendidikan di sekolah tanpa memiliki kesiapan mental untuk menghadapi pekerjaan dengan berbagai tantangan, pemahaman terhadap diri sendiri seperti tertera kepemilikan kompetensi kepribadian dan pemahaman terhadap orang lain tercermin kompetensi sosial, inisiatif, kreativitas sebagai cerminan dari kompetensi manajerial, integritas, keberanian untuk berhasil, dan berprestasi merupakan aplikasi dari penguasaan kompetensi kewirausahaan dan supervisi.

Sementara itu, keberhasilan kepala sekolah dalam membangun watak kewibawaan, mengembangkan potensi, integritas, dan tujuan hidup dan yang terpenting merasakan peluang dan menciptakan masa depan, membangun titik temu, inovasi, intuitif, transformasi situasional, dan kecerdasan yang luwes. Keseluruhan aspek itu, merupakan kekuatan bagi kepala sekolah dalam mengelola sekolahnya untuk mencapai keberhasilan, diperlukan pembahasan tentang berbagai kompetensi yng harus dikuasai oleh seorang kepala sekolah.

Dalam menghadapi tantangan masa depan yang semakin terasa kompleks dan akan berkembang semakin dinamis, diperlukan kompetensi kepemimpinan kepala sekolah berupa conception yang tepat, competency yang cukup, connection yang luas, dan confidence. Kenyataan penngelolaan sekolah yang dihadapi untuk dapat berubah ke arah yang lebih baik tidak hanya dapat dilakukan dengan menunggu instruksi atau kebijakan dari atasan atau orang lain, pengelola sekolah dapat memberikan alternatif tindakan secara bijak dengan menggunakan kemampuan yang dimiliki yaitu kompetensinya

Mengingat tanggung jawab dan perannya dalam memajukan sekolah, maka kriteria kepala sekolah diatur dalam Peraturan Pemerintah Republik Indonesia Nomor 19 Tahun 2005 tentang Standar Nasional Pendidikan pada Pasal 38 ayat (3) dinyatakan sebagai berikut (1) memiliki kualifikasi akademik dan kompetensi sebagai agen pembelajaran, (2) memiliki pengalaman mengajar sekurang-kurangnya lima tahun, dan (3) memiliki kemampuan kepemimpinan dan kewirausahaan di bidang pendidikan. Keberhasilan kepemimpinan kepala sekolah dalam mengelola pendidikan dipengaruhi oleh kemampuan untuk melakukan kegiatan perencanaan (planning), pengorganisasian (organizing), pengarahan (actuating), dan pengawasan (controling) terhadap semua operasional tingkat satuan pendidikan. Keberhasilan sekolah dalam meraih mutu pendidikan yang baik banyak ditentukan melalui peran kepemimpinan kepala sekolah.

\section{Iklim Organisasi Sekolah}

Iklim organisasi dapat dideskripsikan sebagai kombinasi pembagian sejarah, harapan, hukum yang tidak tertulis dan sosial yang mempengaruhi kebiasaan/tingkah laku dari setiap orang di dalam organisasi. Atau suatu garis kepercayaan yang selalu mewarnai persepsi dari setiap tindakan dan komunikasi. Sementara itu Steers (1977) iklim organisasi merupakan lingkungan internal yang mewakili faktor-faktor dalam organisasi yang menciptakan kultur dan lingkungan sosial dimana aktivitas pencapaian tujuan berlangsung. Menurut Delp (1977) iklim organisasi adalah kualitas relatif dari lingkungan internal suatu organisasi, yang dialami dan mempengaruhi perilaku anggotanya, dan dapat digambarkan dalam suatu perangkat karakteristik, apabila dikaitkan dengan budaya, budaya lebih cenderung pada nilai, norma, dan tradisi organisasi. Dengan kata lain, budaya adalah filosofi suatu organisasi, sedangkan iklim organisasi adalah atmosfir dari sebuah organisasi.

Berarti bahwa iklim organisasi meliputi beberapa unsur yang dapat menjadikan organisasi dijiwai oleh semua anggotanya dalam suatu organisasi termasuk organisasi sekolah. Duncon (1972) mencirikan iklim organisasi sebagai keseluruhan faktor fisik dan sosial yang terdapat dalam sebuah organisasi. Sergiovanni (1987) berpendapat bahwa iklim secara umum diciptakan, dibentuk dan disalurkan sebagai hasil dari suatu kepemimpinan interpersonal yang efektif oleh pimpinan sekolah. Pines (1982:176) iklim kerja sebuah organisasi dapat diukur melalui empat dimensi sebagai berikut: (a) dimensi psikologikal, yaitu variabel beban kerja, kurang otonomi, kurang pemenuhan sendiri (self-fulfilment clershif), dan kurang inovasi, (b) dimensi struktural, yaitu variabel seperti fisik, bunyi dan tingkat keserasian antara keperluan kerja dan struktur fisik, (c) dimensi sosial, yaitu aspek interaksi dengan klien 
(dari segi kuantitas dan ciri permasalahannya), rekan sejawat (tingkat dukungan dan kerja sama), dan penyelia-penyelia (dukungan dan imbalan), (d) dimensi birokratik, yaitu undang-undang dan peraturan-peraturan konflik peranan

Selaras dengan itu, iklim sekolah yang positif merupakan suatu kondisi dimana keadaan sekolah dan lingkungannya dalam keadaan aman, damai, dan menyenangkan untuk kegiatan belajar mengajar. Pada hakekatnya iklim bersifat interpersonal dan dimanifestasikan dalam sikap dan perilaku guru, siswa dan pimpinan sekolah dalam kegiatan kerjanya. Selain itu, iklim merupakan energi yang terdapat di dalam organisasi yang dapat memberikan pengaruhnya terhadap sekolah, seperti peraturan yang disepakati untuk mewujudkan tujuan bersama, dukungan teman sejawat dalam membangun kolaborasi di sekolah, kenyamanan kantor mendukung kondisi yang kondusif, kesemuannya itu tergantung bagaimana energi tersebut di salurkan dan diarahkan oleh pimpinan sekolah. Semakin baik energi yang disalurkan dan diarahkan maka semakin baik pula pengaruhnya terhadap sekolah.

Indikator keberhasilan kepala SMK dalam Peraturan Pemerintah No: 19 Tahun 2005 ditegaskan bahwa salah satu tugas kepala sekolah adalah menjaga iklim kerja. Iklim kerja yang dimaksud adalah penciptaan lingkungan sekolah yang baik seperti kebersihan, keindahan ketertiban, keamanan, kerindangan dan kekeluargaan sebagai bagian yang tak terpisahkan dari profesionalisme. Seluruh warga sekolah dengan situasi yang nyaman diharapkan dapat mengaktualisasikan ide, kreativitas, inovasi, kerjasama, dan kompetisi yang sehat di antara guru. Kenyamanan kerja dibutuhkan penataan ruangan kerja yang baik, penerangan ruangan yang cukup, ventilasi udara yang memadai, menjauhkan dari suara bising Kartono (2006:26). Fasilitas-fasilitas kebutuhan lainnya seperti kamar mandi yang bersih, air yang cukup selalu tersedia. Ruangan memberikan komunikasi yang baik antar individu serta memberi rasa nyaman kepada yang menempati. Hubungan antar individu yang akrab serta lingkungan kerja yang mendukung tidak menimbulkan stres kerja karena hubungan antara individu dijalin secara baik dan kekeluargaan. Kartono (2006:28) menemukan bahwa suasana sekolah memberikan kontribusi tidak langsung terhadap kinerja para guru di SMK.

Iklim organisasi sekolah dapat dipandang sebagai aset dari suatu organisasi yang dapat digunakan untuk menciptakan nilai bagi organisasi melalui kombinasi modal manusia dan modal struktural. Iklim organisasi disini dapat dimaknai sebagai suatu karakteristik dari sebuah sekolah dalam suatu organisasi yang dipersepsi oleh para guru dan sekaligus mempengaruhi perilakunya dalam melaksanakan tugasnya.

\section{Etos Kerja}

Etos kerja yang tinggi seyogyanya dimiliki setiap pegawai atau kepala sekolah di suatu sekolah, ini sangat membutuhkan kerja keras dan komitmen yang tinggi dari setiap pegawai, kalau tidak organisasi akan sulit berkembang, dan memenangkan persaingan dalam merebut pangsa pasarnya. Setiap organisasi seperti sekolah menengah kejuruan selalu ingin maju, akan melibatkan anggota untuk meningkatkan mutu kinerjanya, diantaranya setiap sekolah harus memiliki etos kerja. Siagian (2006) seorang pegawai memiliki etos kerja yang tinggi, apabila menunjukkan tanda-tanda sebagai berikut, (1) mempunyai penilaian yang sangat positif terhadap hasil kerjanya; (2) menempatkan pandangan tentang kerja, sebagai suatu hal yang amat luhur bagi eksistensi manusia; (3) kerja yang dirasakan sebagai aktivitas yang membutuhkan ketekunan dan sekaligus sarana yang penting dalam mewujudkan cita-cita; (4) kerja dilakukan sebagai bentuk ibadah.

Etos kerja menggambarkan suatu sikap, sebagai aspek evaluatif yang dimiliki oleh individu (kelompok) dalam memberikan penilaian terhadap kegiatan kerja. Etos kerja yang dimiliki oleh seseorang atau kelompok masyarakat, akan menjadi sumber motivasi bagi perbuatannya, karena itu akan membuka pandangan dan sikap kepada manusianya untuk menilai tinggi terhadap kerja keras dan sungguh-sungguh, sehingga dapat mengikis sikap kerja yang asal-asalan, tidak berorientasi terhadap mutu atau kualitas yang semestinya. Siagian (2006) mengatakan bahwa turun/rendahnya semangat dan kegairahan diindikasikan oleh: (1) turun/rendahnya produk- 
tivitas; (2) tingkat absensi yang naik/ rendah; (3) labour turn over (tingkat perputaran buruh) yang tinggi; (4) tingkat kerusuhan yang naik; (5) kegelisahan dimana-mana; (6) tuntutan yang sering terjadi; dan (7) pemogokan.

Peningkatan etos kerja dapat dilakukan dengan berbagai cara, antara lain melalui Sinamo (1999:78) (1) komunikasi secara interaktif walaupun dalam banyak perbedaan; (2) menegakkan disiplin kerja; (3) menumbuhkan komitmen dan kesadaran akan tanggung jawab; (4) kerja sama yang solid dan transparan; dan (5) menciptakan iklim kerja yang kondusif. Etos kerja yang tinggi biasanya muncul karena berbagai tantangan, harapan, dan kemungkinan kemungkinan yang menarik. Situasi itu, dapat membuat seseorang seperti guru atau kepala sekolah itu, bekerja dengan rajin, teliti, berdedikasi, serta tanggung jawab yang besar, perilaku kerja yang konsisten positif, berwatak ramah budaya, dan serasi lingkungan, komitmen terhadap visi organisasi, serta orientasi kerja pada keunggulan insani berdasarkan the spirit of success.

Dilandasi etos kerja yang tinggi akan diraih berbagai hasil, baik untuk kepentingan lembaga, Sinamo (1999:78) menegaskan sebagai berikut (1) mencapai aktualisasi diri; (2) tercapainya kepuasan; (3) pengembangan karier pegawai secara adil; (4) melakukan retensi secara selektif; (5) meningkatkan disiplin; (6) meningkatkan motivasi dan moral kerja; (7) meningkatkan produktivitas kerja; (8) meningkatkan kerja sama; (9) menumbuhkan konflik positif.Peningkatan etos kerja dapat dilakukan dengan berbagai cara, Sinamo (1999:112) dapat berupa (1) komunikasi secara interaktif walaupun dalam banyak perbedaan; (2) menegakkan disiplin kerja; (3) menumbuhkan komitmen dan kesadaran akan tanggung jawab; (4) kerja sama yang solid dan transparan; dan (5) menciptakan iklim kerja yang kondusif.

Berbekal etos kerja professional yang melatarbelakangi munculnya moral dan perilaku kerja pegawai, maka pada gilirannya dapat mendorong organisasi untuk menampilkan kinerja tinggi, diharapkan akan menumbuhkan kemauan, kemampuan, dan kesediaan seseorang untuk menyesuaikan perilakunya dengan budaya dan tuntutan organisasi, sehingga termotivasi untuk meningkatkan produktivitas kerjanya. Untuk itu, diperlukan adanya kejelasan visi, misi, komitmen, integritas, kretivitas, daya tahan atas berbagai tantangan dan ancaman dan yang terpenting adalah adanya kemauan untuk bekerja keras demi organisasi.

Berdasar kajian teori itu, hipotesisnya adalah (1) Ada kontribusi variabel kompetensi kepala sekolah terhadap kepemimpinan transformasional kepala sekolah. (2) Ada kontribusi variabel iklim organisasi sekolah terhadap kepemimpinan transformasional kepala sekolah. (3) Ada kontribusi variabel etos kerja terhadap kepemimpinan transformasional kepala sekolah. (4) Ada kontribusi variabel kompetensi kepala sekolah, iklim organisasi serta etos kerja secara bersamasama terhadap model kepemimpinan transformasional kepala sekolah.

\section{Metode dan Prosedur Analisis}

Jenis penelitian ini bersifat deskriptif korelasional, dengan desain model ditentukan dahulu landasan teorinya, kemudian model diuji signifikansinya dengan menggunakan data yang dikumpulkan. Besaran populasi 573 guru SMK Negeri dikedua daerah penelitian, terpilih 200 sampel, pengambilan sampel ini, sesuai dengan yang dipersyaratkan dalam Structural Equation Modeling (SEM) dalam analisis LISREL (Ghozali 2005:13) Data dikumpulkan dengan angket skala berstruktur, yang mengungkap penilaian guru terhadap kepala sekolah. Disain model pengukurannya berpendekatan confirmatory factor analysis melalui LISREL (Joreskog, Sorbom, 1986 dalam Ghozali, 2005:37).

Data dianalisis melalui statistik deskriptif berbantuan soft ware SPSS versi 13.00 for Windows dan analisis koefisien determinasi dengan bantuan soft ware LISREL versi 8,51 windows application melalui media komputer (Ghozali 2005:8). Uji tingkat kesahihan instrumen dilakukan dengan validitas isi (content validity) dan validitas konstruk (construct validity). Instrumen dari sisi konstruk, akan digunakan pendapat para ahli (judgment experts). Analisis instrumen menggunakan program SPSS dengan menggunakan formula Cronbach's Alpha yakni matrik interkorelasi antar skor item atau butir instrumen. Dari enam variabel laten, yang diuji reliabilitasnya 
dengan Cronbach's Alpha, seluruh butir instrumen dinyatakan reliabel

Permodelan persamaan struktural terdiri atas delapan langkah yaitu: (1) pengembangan model berbasis teori dengan concise theoretical model. (2) penyusunan diagram alur, dibangun secara nomothetic-explanation, prediction dan control lalu causal model secara diagram alur (path diagram). (3) spesifikasi model dengan model pengukuran (measurement model). (4) identifikasi model yaitu menjaga model agar tidak under-identified atau unidentified. (5) estimasi parameter, membangun data menghasilkan matriks kovarian berdasarkan model (model-based covarians model). (6) penilaian model fit, dengan indikator goodness of fit (GOF).(7) modifikasi model, untuk memperoleh model fit (goodness of fit) dalam bahasa statistik, untuk memperoleh nilai selisih yang terkecil antara kovarian matrik sampel dengan kovarian matrik model. Pengukuran variabel laten untuk mengukur indikator variabel yang mempengaruhi sebuah variabel laten, digunakan teknik confimatory factor analiysis.

\section{Hasil Penelitian dan Bahasan}

Kepemimpinan transformasional kepala sekolah berdasarkan analisis deskriptif variabel pengukurannya diperoleh mean sebesar 95,805 yang terletak pada interval 89-109, bahwa kepemimpinan transformasional kepala sekolah menurut persepsi guru adalah baik. Kompetensi Kepala Sekolah analisis dari variabel laten beserta variabel pengukurannya yang terdiri atas 37 butir pertanyaan, skor terendah 37 dan skor tertinggi 185, range 148 dan kelas interval 29. mean sebesar 135,8 yang terletak pada interval 128156 menurut persepsi guru adalah baik Variabel iklim organisasi sekolah berdasarkan analisis deskriptif, dari variabel laten beserta variabel pengukurannya yang terdiri atas 14 butir pertanyaan diperoleh mean sebesar 51,635 yang terletak pada interval 49-59, berarti iklim organisasi sekolah dipersepsi guru adalah baik Etos kerja berdasarkan analisis deskriptif, variabel laten etos kerja beserta variabel pengukurannya yang terdiri dari 25 butir pertanyaan, diperoleh mean sebesar 93,92 yang terletak pada interval 86-105, menurut persepsi guru adalah baik.

\section{Analisis Faktor Konfirmatori.}

Dalam penilaian model structural terfokus pada hubungan antara variabel laten eksogen dan endogen, rumusan hipotesis yang ditetapkan dalam model semua dalam bentuk positif, sehubungan itu perhitungan dari LISREL menunjukkan tidak adanya hubungan negatif antara variabel eksogen dan endogen. Analisis faktor konfirmatori variabel eksogen dan endogen digunakan untuk menguji kesesuaian model terhadap data yang digunakan.

\section{Variabel Kompetensi Kepala Sekolah}

Pengukuran konfirmatori variabel kompetensi kepala sekolah $\left(\hat{\imath}_{1}\right)$, diukur dengan lima indikator yang dinotasikan $\left(\mathrm{X}_{1}, \mathrm{X}_{2}, \mathrm{X}_{3}, \mathrm{X}_{4}, \mathrm{X}_{5}\right.$ ) hasil pengujian dinyatakan goodness of fit, dibuktikan dari nilai koefisien chi square yang kecil $(3,345)$ dari nilai Chi-Square tabel sebesar 11,075. Nilai itu bila dikonfirmasikan dengan cut of value ( lebih kecil dari tabel chi square pada tingkat $a=0,05 ; \mathrm{DF}=5$ ). Simpulan yang diperoleh model pengujian konfirmatori kompetensi kepala sekolah telah sesuai dengan data empiris. Besarnya koefisien regression adalah

\section{Variabel Iklim Organisasi Sekolah}

Pengukuran konfirmatori variabel iklim organisasi sekolah $\left(\hat{i}_{2}\right)$ sebagai variabel latent eksogen kedua, memiliki empat indikator $\left(\left(X_{6}, X_{7}, X_{8}, X_{9}\right)\right.$ atau variabel pengamatan. Pengujian terhadap

Tabel 1. Koefisien Regresi Variabel Kompetensi Kepala Sekolah

\begin{tabular}{|l|c|c|c|c|}
\hline \multicolumn{1}{|c|}{ Regression Weights } & Estimate & S.E. & C.R. & $P$ \\
\hline$X_{1} \rightarrow$ Kompetensi Kepala Sekolah & 0.751 & - & - & 0,000 \\
\hline$X_{2} \rightarrow$ Kompetensi Kepala Sekolah & 0.867 & 0.215 & 11.900 & 0,000 \\
\hline$X_{3} \rightarrow$ Kompetensi Kepala Sekolah & 0.723 & 0,070 & 9,971 & 0,000 \\
\hline$X_{4} \rightarrow$ Kompetensi Kepala Sekolah & 0.671 & 0.070 & 9.214 & 0,000 \\
\hline$X_{5} \rightarrow$ Kompetensi Kepala Sekolah & 0.776 & 0.054 & 10.740 & 0,000 \\
\hline
\end{tabular}


variabel konfirmatori iklim organisasi sekolah dinyatakan goodness of fit, dibuktikan dari nilai koefisien chi square yang kecil yaitu sebesar 0,214 dari nilai Chi-Square tabel sebesar 5,992 (lebih kecil dari tabel chi square pada tingkat $\alpha=0,05$; $\mathrm{DF}=5$ ), Simpulan yang diperoleh model pengujian konfirmatori iklim organisasi sekolah telah sesuai dengan data empirik. Besarnya koefisien regression dapat dilihat pada Tabel 2 berikut.

\section{Variabel Etos Kerja}

Pengukuran konfirmatori etos kerja $\left(\hat{i}_{3}\right)$ sebagai variabel laten eksogen ketiga memiliki 5 indikator $\left(\mathrm{X}_{10}, \mathrm{X}_{11}, \mathrm{X}_{12}, \mathrm{X}_{13}, \mathrm{X}_{14}\right)$, pengujian terhadap variabel konfirmatori pada dimensi etos kerja dinyatakan fit secara baik, ini dibuktikan dari nilai koefisien chi square yang kecil sebesar 7,138 dari nilai ChiSquare tabel sebesar 11,075 pada tingkat $\alpha=$ 0,05 ; DF $=5$ ). Simpulan model pengujian konfirmatori etos kerja telah sesuai dengan data. Besaran koefisien regression tampak pada Tabel 3 berikut ini.

\section{Pengujian Konfirmatori Variabel Eksogen}

Pengukuran konfirmatori variabel-variabel eksogen, yaitu variabel yang menjelaskan terdiri dari tiga variabel laten yaitu : variabel kompetensi kepala sekolah $\left(\hat{i}_{1}\right)$; variabel iklim organisasi sekolah $\left(\hat{i}_{2}\right)$ dan variabel etos kerja $\left(\hat{i}_{3}\right)$. Pengujian terhadap variabel eksogen dapat dilihat pada Gambar 1 di bawah ini.

Tabel 2 Koefisien Regresi Variabel Iklim Organisasi Sekolah

\begin{tabular}{|l|c|c|c|c|}
\hline Regression Weights & Estimate & S.E. & C.R. & $P$ \\
\hline$X_{6} \rightarrow$ Iklim Organisasi Sekolah & 0.722 & - & - & 0,000 \\
\hline$X_{7} \rightarrow$ Iklim Organisasi Sekolah & 0.832 & 0.086 & 11.044 & 0,000 \\
\hline$X_{8} \rightarrow$ Iklim Organisasi Sekolah & 0.811 & 0,086 & 10,787 & 0,000 \\
\hline$X_{9} \rightarrow$ Iklim Organisasi Sekolah & 0.864 & 0.106 & 11.379 & 0,000 \\
\hline
\end{tabular}

Tabel 3 Koefisien Regresi Variabel Etos Kerja

\begin{tabular}{|l|c|c|c|c|}
\hline Regression Weights & Estimate & S.E. & C.R. & $P$ \\
\hline $\mathrm{X}_{10} \rightarrow$ Etos Kerja & 0.756 & & & 0,000 \\
\hline $\mathrm{X}_{11} \rightarrow$ Etos Kerja & 0.749 & 0.098 & 10.866 & 0,000 \\
\hline $\mathrm{X}_{12} \rightarrow$ Etos Verja & 0.836 & 0,159 & 12,324 & 0,000 \\
\hline $\mathrm{X}_{13} \rightarrow$ Etos Verja & 0.859 & 0.135 & 12.699 & 0,000 \\
\hline $\mathrm{X}_{14} \rightarrow$ Etos Kerja & 0.913 & 0.138 & 13.584 & 0,000 \\
\hline
\end{tabular}

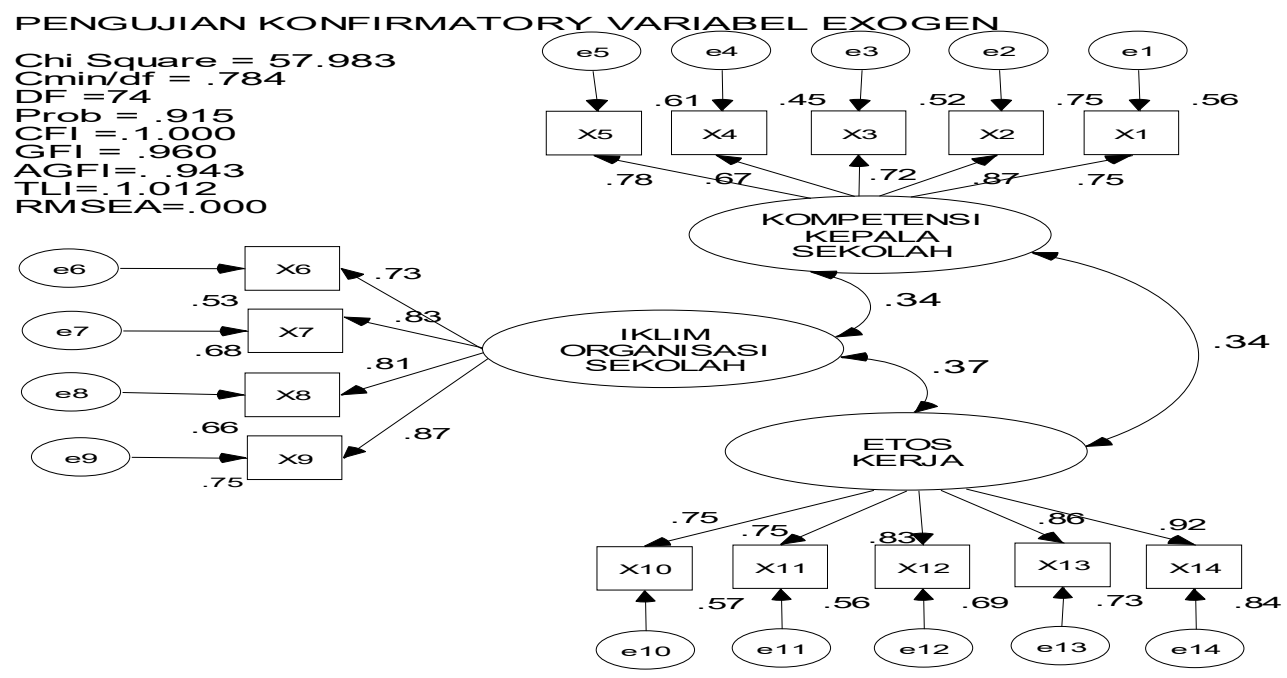

Gambar 1 Pengujian Konfirmatori Variabel Eksogen 
Gambar 1 itu, dapat dikemukankan bahwa pengujian konfirmatori variabel eksogen dinyatakan fit secara baik, ini dibuktikan dari nilai koefisien chi square yang kecil yaitu sebesar 57,983 dari nilai Chi-Square tabel sebesar 135,609. pada tingkat $a=0,05 ; \mathrm{DF}=74$ ). Model pengujian konfirmatori variabel eksogen telah sesuai dengan data empiris. Besarnya koefisien regression, variabel eksogen dinyatakan signifikan pada taraf $\alpha / 2(0,025)$, atau sama dengan $\pm 1,96$. Melalui perbandingan antara nilai CR (critical ratio) dengan nilai $Z$ tabel, ternyata untuk semua dimensi terbukti lebih besar dari nilai $Z$ tabel, atau dilihat dari nilai probability $(P)$ yang semua dimensi lebih kecil dari 0,05. Sehingga dapat disimpulkan bahwa koefisien factor loading yang dihasilkan untuk semua dimensi pada variabel-variabel eksogen dinyatakan signifikan.

\section{Variabel Kepemimpinan Transformasional Kepala Sekolah}

Pengukuran konfirmatori kepemimpinan transformasional kepala sekolah sebagai variabel laten endogen, dimana memiliki tiga indikator. Pengujian terhadap variabel konfirmatori kepemimpinan transformasional kepala sekolah dinyatakan fit secara baik, ini dibuktikan dari nilai koefisien chi square yang kecil 2,324 dari nilai ChiSquare tabel sebesar 5,992 pada tingkat $=0,05$ ; $D F=3$ ), diperoleh. Simpulan yang diperoleh model pengujian konfirmatori kepemimpinan kepala sekolah telah sesuai dengan data empirik. Besarnya koefisien regression dapat dilihat pada Tabel 4.

\section{Pengujian Full Model SEM}

Pengujian Full model Structural Equation (SEM) untuk menguji hipotesis yang diajukan dan menjawab rumusan masalah yang ditetapkan didepan.

Pengujian full model Structural Equation Model (SEM) dapat dilihat pada Gambar 2 berikut ini.

\section{Uji Kelayakan Structural Equation Model}

Hasil analisis ini dikemukakan kepemimpinan transformasional kepala sekolah beserta faktor

Tabel 4 Koefisien Regresi Variabel Kepemimpinan Kepala Sekolah

\begin{tabular}{|l|c|c|c|c|}
\hline Regression Weights & Estimate & S.E. & C.R. & $P$ \\
\hline$Y_{1} \rightarrow$ Kepemimpinan Kepala Sekolah & 0.915 & - & - & 0,000 \\
\hline$Y_{2} \rightarrow$ Kepemimpinan Kepala Sekolah & 0.719 & 0.062 & 8.627 & 0,000 \\
\hline$Y_{3} \rightarrow$ Kepemimpinan Kepala Sekolah & 0.650 & 0,039 & 8,18 & 0,000 \\
\hline
\end{tabular}

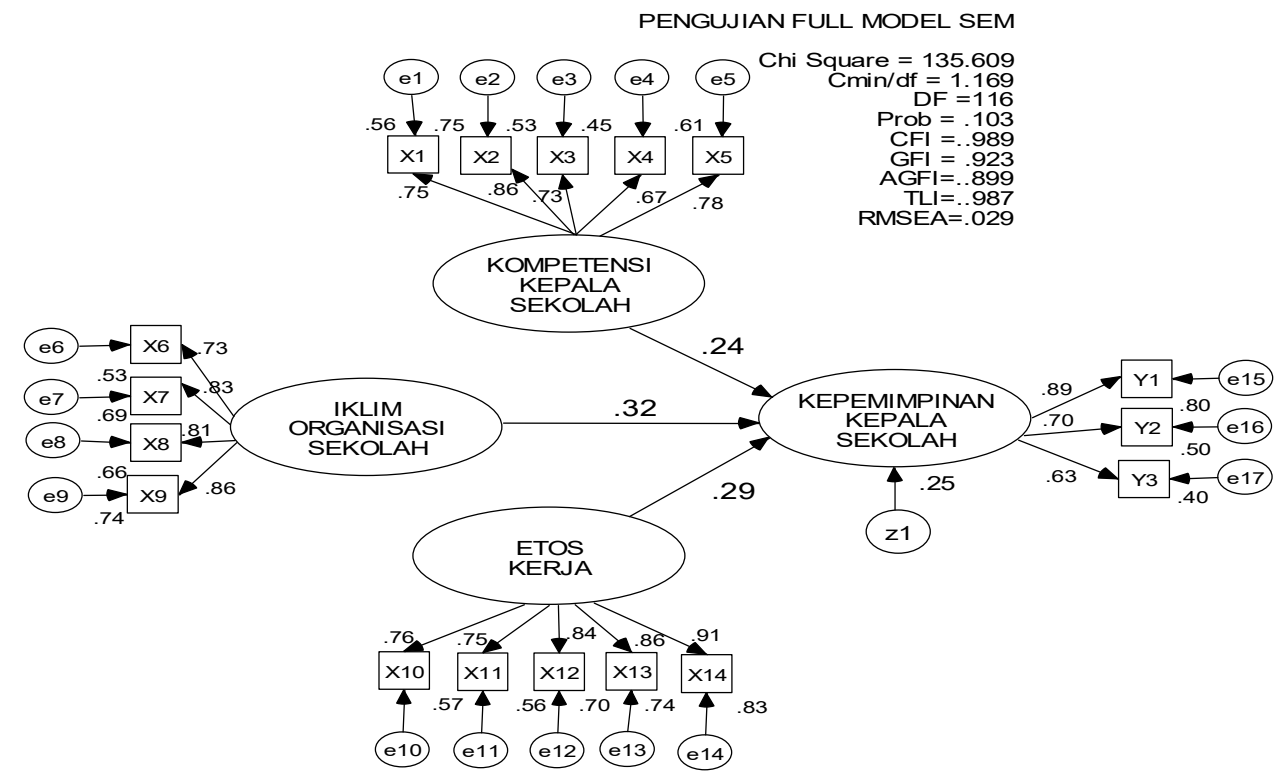

Gambar 2 Full Structural Equation Model (SEM) 
determinan yang mempengaruhinya, yaitu kompetensi kepala sekolah, iklim organisasi sekolah dan etos kerja. Hubungan struktural yang diuji mengasumsikan bahwa kepemimpinan transformasional kepala sekolah dipengaruhi oleh ketiga faktor tersebut. Dari gambar 2 itu, dapat dikemukakan bahwa model structural equation model (SEM) dinyatakan fit secara baik, hal ini dibuktikan dari kelayakan nilai-nilai uji seperti ditunjukkan dalam Tabel 5 sebagai berikut. juga dapat diketahui berdasarkan signifikasi t hitung dengan nilai probabilitas $(p)=0,05$. Hasil bobot regresi uji kausalitas sebagai berikut: hubungan antara variabel latent dengan dimensidimensinya dapat dijelaskan pada Tabel 7 sebagai berikut.

\section{Pembahasan}

Hipotesis kerja dapat diterima yaitu untuk mengetahui apakah ada kesesuaian antara model

Tabel 5 Indeks Pengujian Kelayakan Structural Equation Modelling

\begin{tabular}{|l|l|c|c|c|}
\hline No & Goodness of fit index & Cut of value & Hasil analisis & Evaluasi Model \\
\hline 1 & $X^{2}-$ Chi-Square & $<141.030$ & 135,609 & Baik \\
\hline 2 & Significancy Probability & $>0,05$ & 0,103 & Baik \\
\hline & CFI & $>0,90$ & 0,989 & Baik \\
\hline 3 & GFI & $>0,90$ & 0,923 & Baik \\
\hline 4 & AGFI & $>0,90$ & 0,899 & Baik \\
\hline 5 & TLI & $>0,95$ & 0,987 & Baik \\
\hline 6 & RMSEA & $<0,08$ & 0,029 & Baik \\
\hline
\end{tabular}

Tabel 6 Evaluasi Bobot Regresi Uji Kausalitas

\begin{tabular}{|l|c|c|c|c|}
\hline \multicolumn{1}{|c|}{ Regression Weights } & Estimate & S.E. & C.R. & P \\
\hline $\begin{array}{l}\text { Kompetensi Kepala Sekolah } \rightarrow \\
\text { Kepemimpinan Kepala Sekolah }\end{array}$ & 0.245 & 0.074 & 2.869 & 0,000 \\
\hline $\begin{array}{l}\text { Iklim Organisasi Sekolah } \rightarrow \\
\text { Kepemimpinan Kepala Sekolah }\end{array}$ & 0,294 & 0,112 & 3,725 & 0,000 \\
\hline $\begin{array}{l}\text { Etos Kerja } \rightarrow \text { Kepemimpinan Kepala } \\
\text { Sekolah }\end{array}$ & 0.281 & 0.053 & 3.529 & 0,000 \\
\hline
\end{tabular}

Tabel 5 itu, menunjukkan bahwa model yang direncanakan fit secara baik, karena setelah diuji kecocokannya nilai Chi Square, GFI, AGFI, TLI, dan RMSEA dibandingkan dengan nilai acuan (cut of value) persamaan model structural, hasilnya baik, nilai probabilitas ( $p$ value) chi square 0,103 $>0,05$. Uji ini dapat menyimpulkan bahwa model sudah sesuai dengan data yang digunakan. Berdasarkan out put LISREL, terlihat bahwa arah hubungan antara variabel eksogen dengan variabel endogen menunjukkan arah hubungan positif, dan tidak ada satupun variabel yang menunjukkan hubungan negatif.

\section{Pengujian Kausalitas Model}

Melalui program statistik AMOS dapat dianalisis dan dihitung hasil bobot regresi antar variabel laten yang sering disebut sebagai estimasi loading factors atau lambda value. Selain itu derajat bebas atau deggre of freedom (DF), nilai CR atau t hitung yang diajukan, dapat dinyatakan bahwa hipotesis kerja adalah (1) Terdapat pengaruh secara signifikan kompetensi kepala sekolah terhadap kepemimpinan transformasional kepala sekolah sebesar 24,5\%. Hasil analisis juga ditemukan pembentuk konstruk secara berturut-turut yaitu kompetensi kepribadian sebesar 74,7\%, manajerial $86,5 \%$, kewirausahaan sebesar $72,6 \%$, supervisi $67 \%$, dan kompetensi sosial sebesar $77,9 \%$. Kompetensi kepala sekolah yang mempunyai pengaruh positif dan signifikan terhadap kepemimpinan kepala sekolah, sesuai teori Spencer (1993) yang menyatakan bahwa karakteristik dasar seorang pekerja yang menggunakan bagian kepribadiannya yang paling dalam, dan dapat mempengaruhi perilakunya ketika ia menghadapi pekerjaan yang akhirnya mempengaruhi kemampuan untuk menghasilkan prestasi kerjanya, sesuai dengan Permendiknas No 13 Tahun 2007 tentang Standar kepala 
sekolah bahwa komptenasi manajerial seorang kepala sekolah penting untuk mengelola sekolahnya maencapai mutu pendidikan.

Kompetensi kepala sekolah akan menentukan kinerjanya dalam hal ini kepemimpinannya yang dapat mendayagunakan sumberdaya secara optimal untuk kepentingan sekolah. Kondisi ini menggambarkan bahwa kepala sekolah yang mempunyai kompetensi tinggi maka kepemimpinannya semakin baik dalam mencapai tujuan sekolah sesuai dengan perencanaan sekolah (2) Terdapat pengaruh secara signifikan iklim organisasi sekolah terhadap kepemimpinan transformasional kepala sekolah sebesar $29,4, \%$. Hasil analisis juga membuktikan pembentuk konstruk terbesar dalam iklim organisasi adalah dimensi birokratik yaitu sebesar $86,2 \%$, hal ini menggambarkan bahwa iklim organisasi yang ada di sekolah akan banyak ditentukan oleh birokrasi yang ada di sekolah tesebut. Temuan ini juga didukung oleh Steve Kelneer yang dikutip oleh Spencer (1993) disebutkan bahwa flexibility conformity. Fleksibilitas dan comfomity merupakan kondisi organisasi yang untuk memberikan keleluasan bertindak bagi warga belajar baik guru, tenaga kependidikan dan peserta didik serta melakukan penyesuaian diri terhadap tugastugas yang diberikan. Hal ini berkaitan dengan aturan yang ditetapkan organisasi, kebijakan dan prosedur yang ada.

Penerimaan terhadap ide-ide yang baru merupakan nilai pendukung di dalam mengembangkan iklim organisasi yang kondusif demi tercapainya tujuan organisasi, dalam mencapai tujuan diperlukan iklim organisasi sekolah yang kondusif yang diciptakan oleh kepala sekolah selaku headmaster. Temuan penelitian ini pembentuk dimensi iklim organisasi sekolah yang terbesar, hal ini berarti bahwa kepemimpinan kepala sekolah adalah faktor kunci untuk mengelola mencapai visi dan misi sekolah melalui penciptaan iklim yang baik. Kondisi ini menggambarkan bahwa iklim organisasi sekolah yang baik dapat mempengaruhi kepemimpinan kepala sekolah dalam melaksanakan tugasnya mengelola sekolah. Semakin baik iklim organisasi sekolah maka kepemimpinan kepala sekolah semakin efektif. (3) Terdapat pengaruh secara signifikan iklim organisasi sekolah terhadap kepemimpinan transformasional kepala sekolah sebesar $28,1, \%$. Hasil analisis juga membuktikan signifikan, nilai probability $(P)$ lebih kecil dari 0,05 , dari nilai $C R$ sama dengan 3,529 , terbukti lebih besar dari nilai tabel $Z \pm 1,96$.

Kondisi ini menggambarkan bahwa etos kerja yang tinggi akan menentukan kepemimpinan kepala sekolah, temuan dalam penelitian adalah adanya komitmen yang tinggi terhadap pencapaian tujuan organisasi sekolah maka kepemimpinan kepala sekolah akan berjalan semakin baik atau efektif. Komitmen terhadap visi organisasi yang tinggi, dijelaskan oleh Sinamo menjadi tri darma mahardika artinya tiga jalan keberhasilan yang meliputi (1) mencetak prestasi dengan motivasi yang tinggi dan keterampilan yang dimiliki dalam hal ini adalah kepemimpinan kepala sekolah dalam memimpin. Prestasi yang dicapai merupakan budaya mutu; (2) membangun masa depan kepemimpinan yang transformasional dan visioner. Sukses selalu dikaitkan dengan aspirasi kemudian mewujudkan visi, misi, atau purpose of life. Kepemimpinan visioner adalah piranti utama untuk mewujudkan impian menjadi kenyataan, cita-cita menjadi realita, dan misi menjadi kondisi; (3) mencipta nilai baru dengan inovatif dan kreatif. Etos kerja yang tinggi dari kepala sekolah dapat menjadikan misi menjadi target mutu sesuai dengan program sekolah yang pada akhirnya akan meningkatkan mutu pendidikan secara keseluruhan melalui kepemimpinannya. (4), Terdapat pengaruh secara signifikan iklim organisasi sekolah berpengaruh terhadap kepemimpinan transformasional kepala sekolah sebesar 28,1,\%. Hasil analisis juga membuktikan signifikan, nilai probability $(P)$ lebih kecil dari 0,05, yang dapat dilihat dari nilai CR sama dengan 3,529, perolehan lebih besar dari nilai tabel $Z \pm 1,96$. Penciptaan iklim organisasi yang kondusif dapat berdampak pada peningkatan kinerja secara optimal dalam mewujudkan tujuan sekolah yang berbasis kewirausahaan. Kultur yang "sehat" berkorelasi tinggi dengan motivasi kerja guru, produktivitas, dan kepuasaan kerja kepala sekolah, guru, staf administrasi maupun siswa, melihat dari sisi lain dari upaya peningkatan kerja. (5) Terdapat pengaruh secara bersamasama kompetensi kepala sekolah, iklim organisasi sekolah dan etos kerja terhadap kepemimpinan 
kepala sekolah sebesar $85,6 \%$. Hasil analisis juga membuktikan bahwa dari ketiga variabel laten yang diteliti secara berturut-turut mempunyai pengaruh terhadap kepemimpinan kepala sekolah hampir sama besarnya yaitu kompetensi kepala sekolah sebesar $24,5 \%$, iklim organisasai sekolah sebesar 29,4\%, dan etos kerja sebesar 28,1\%. Walaupun pengaruhnya hampir sama besarnya, namun demikian pengaruh yang paling besar adalah iklim organisasi sekolah yaitu sebesar $29,4 \%$. Sedangkan pengaruh secara keseluruhan sebesar $85,6 \%$ dan terbukti signifikan dengan probability $(P) 0,000$. Kondisi ini menggambarkan bahwa kepemimpinan kepala sekolah sebagai pemimpin sangatlah cocok dengan misi dari pada sekolah sebagai organisasi terbuka dan agent of change, sekolah dituntut inovatif, aspiratif dan tanggap terhadap perkembangan zaman. Kesempatan ini lebih didukung dengan adanya otonomi pendidikan dengan program Manajemen Berbasis Sekolah (School Based Management).

Dengan demikian kepala sekolah mempunyai kewenangan yang lebih luas dalam rangka mengelola sekolah, sehingga dituntut memahami secara komprehensif manajemen sekolah. Kemampuan manajerial yang tinggi menjadikan sekolah efesien, tetapi tidak dikendalikan dengan kemampuan kepemimpinannya yang efektif, maka kepala sekolah akan menjadi manajer yang tangguh yang menggunakan kekuasaannya dengan semena-mena, dengan kurang memperhatikan aspek-aspek moral, etika dan sosial. Kepala sekolah sebagai pemimpin harus memegang pada prinsip utama saat melaksanakan tugasnya yaitu bahwa orang lebih penting ketimbang benda lainnya. Kata kuncinya, agar kepala sekolah berhasil menggerakkan para guru, staf dan para siswa dalam mencapai tujuan sekolah, sehingga kepala sekolah harus mampu menyakinkan (persuade) dan membujuk (induce) agar para guru, staf dan para siswa percaya bahwa apa yang dilakukannya adalah benar. Perbuatan memaksa atau bertindak keras kepada mereka perlu dihindari, namun sebaliknya harus melahirkan kemauan serta semangat bekerja dengan penuh percaya diri dan penuh semangat.

\section{Simpulan}

Hasil analisis deskripsi dapat disimpulkan sebagai berikut: Pemodelan kepemimpinan kepala sekolah pada kondisi sesuai (good fit) dengan data empiris. Pemodelan mampu menjelaskan hubungan struktural yang dibangun pada model tersebut: (1) Faktor dimensi kompetensi kepala sekolah terhadap kepemimpinan transformasional kepala sekolah berkontribusi $24,5 \%$, dan pengaruhnya signifikan. Pembentuk konstruk paling besar adalah kompetensi manajerial dengan nilai estimasi sebesar $86,5 \%$ dan konstruk yang paling kecil adalah kompetensi kepribadian sebesar $67,0 \%$. pemodelan untuk pengembangan kemampuan kepemimpinan kepala sekolah lebih diprioritaskan pada peningkatan jiwa kepemimpinan yang harus dimiliki seorang kepala sekolah.(2) Faktor variabel iklim organisasi sekolah terhadap kepemimpinan transformasional kepala sekolah. berkontribusi 29,4\%, dan pengaruhnya signifikan. Model tersebut dapat digunakan sebagai pemodelan untuk pengembangan iklim organisasi sekolah yang kondusif akan mempengaruhi kepemimpinan transformasional kepala sekolah lebih diprioritaskan pada sudut birokratik dimana seorang kepala sekolah harus memahami job diskripsi. (3) Faktor variabel etos kerja terhadap kepemimpinan transformasional kepala sekolah berkontribusi sebesar $28,1 \%$. Pembentuk konstruk paling besar adalah variabel dimensi komitmen terhadap visi organisasi dengan nilai estimasi sebesar $91,2 \%$, dan konstruk yang paling kecil adalah dimensi absensiteisme yang rendah yaitu sebesar 74,7\%. Model tersebut dapat digunakan sebagai pemodelan untuk pengembangan etos kerja kepala sekolah yang tinggi. (4) Faktor variabel kepemimpinan transformasional kepala sekolah berkontribusi $24,5 \%$. Pembentuk konstruk paling besar adalah variabel pengukuran pada dimensi kharisma dengan nilai estimasi sebesar $89,4 \%$, dan konstruk yang paling kecil adalah dimensi stimulasi intelektual sebesar $63,1 \%$. Model yang dibangun dapat digunakan sebagai pemodelan gaya kepemimpinan kepala sekolah yang mampu memberikan stimulus anak buah secara intelektual.

Model kepemimpinan transformasional kepala sekolah SMK N adalah yang yang berkonfigurasi iklim organisasi sekolah (dengan dimensi-dimensi birokratik, struktural, sosial, dan psikologikal); (kontribusi 29,4\%), etos kerja (dengan dimensi- 
dimensi komitmen organisasi, motivasi, akuntabilitas, moral kerja dan absenteisme); dan kepemilikan kompetensi kepala sekolah (mencakupi kompetensi-kompetensi manajerial, sosial, kepribadian, kewirausahaan, dan supervisi).

Berpijak pada temuan dari model kepemimpinan yang terbangun, dalam merumuskan kepemimpinan kepala sekolah diperlukan peningkatan kemampuan kepala sekolah dalam melaksanakan fungsi manajemennya secara periodik. Peningkatan kemampuan tersebut meliputi upaya peningkatan faktor kompetensi supervisi kepala sekolah kepada guru dan karyawannya disamping faktor jiwa dan mental kewirausahaan bagi guru dan siswa, kompetensi kepribadiaannya, kompetensi sosialnya, dan kompetensi manajerial, disamping minimal mempertahankan kebermaknaan faktor-faktor determinan yang lainnya. Model tersebut dapat digunakan sebagai pemodelan untuk menetapkan siapa sebagai seorang kepala sekolah. tersusun model konseptual pengembangan kapasitas kepemimpinan transformasional yang relevan dengan kebutuhan dan tantangan yang harus direspons oleh SMK Negeri. Model tersebut dapat digunakan sebagai pemodelan dan konstruk untuk pengembangan kemampuan kepemimpinan pasca abad 21.

Kompetensi kepala sekolah merupakan modal yang cukup penting bila sering diasah, jika digunakan secara optimal, justru semakin apresiatif, semakin mampu menjabarkan dimensi kompetensi dalam mengelola sekolah dengan manajemen berbasis sekolah, penciptaan iklim organisasi yang kondusif dapat berdampak pada peningkatan kinerja secara optimal dalam mewujudkan tujuan sekolah yang berbasis kewirausahaan. Kultur yang "sehat" berkorelasi tinggi dengan motivasi kerja guru, produktivitas, dan kepuasaan kerja kepala sekolah, guru, staf administrasi maupun siswa, melihat dari sisi lain dari upaya peningkatan kerja. Mereka berkeyakinan bahwa sistem balas jasa atau sistem imbalan mempunyai dampak sangat besar terhadap motivasi dan etos kerja setiap karyawan, termasuk guru. Lebih lanjut dijelaskan bahwa mutu pendidikan di sekolah itu akan dapat menjadi motivator kuat bagi kinerja seseorang jika dikelola secara efektif.

Kepemilikan etos kerja bagi setiap warga sekolah akan berdampak pada munculnya moral dan perilaku kerja pegawai/guru, kepala sekolah harus mampu mendorong organisasi untuk menampilkan kinerja tinggi, harus dapat dan mampu mempengaruhi bawahannya, mampu meyakinkan kepada setiap staf maupun guru selalu hadir tepat waktu, bekerja secara baik, menggerakkan kepada guru dan karyawan untuk dapat mentaati jam kerja secara tepat. Faktor moderator kompetensi kepala sekolah, iklim organisasi sekolah dan etos kerja, semua harus direncanakan, dikelola, dan dikendalikan secara sinergistik agar dapat berpengaruh positif terhadap transformasi kepemimpinan kepala sekolah yang menjadi kinerja berbasis mutu.

Direkomendasikan kepada berbagai pihak yang terkait sebagai berikut (1) Peningkatan kompetensi kepala sekolah dalam mengelola sekolah, perlu menciptakan iklim organisasi sekolah penekanan utama pada faktor kerjasama, penciptaan iklim sekolah yang kondusif, penciptaan inovasi, peninjauan kembali struktur, proses, dan nilai organisasi agar lebih baik.(2) Perlu penciptaan kondisi lingkungan yang kondusif dan adaptif, merespons aneka perubahan internal dan eksternal, berpikir secara visioner berbasis pada potensi yang ada, memberdayakan diri, mengembangkan mental kewirausahaan, kolaborasi dengan kolega, berpikir inklusif tentang seluruh konstituennya, memperhatikan pemeliharaan disiplin kerja. (3) Perlu formulasi pola rekruitmen kepala sekolah memberikan peluang kepada guru yang berasal dari lingkungan internal dan eksternal sekolah, adalah asfek yang dapat dipertahankan di dalam merekrut kepala sekolah. Aspek lain yang seharusnya mendapat perhatian oleh dinas adalah, kesinambungan pembinaan kepala sekolah, penyerahan tanggungjawab penuh atas kelangsungan sekolah. (4) Perlu pencarian alternatif mengenai beragam model yang memungkinkan diformulasikannya kepemimpinan transformasional kepala sekolah, kompetensi kepala sekolah, iklim organisasi sekolah, etos kerja, dan kebermutuan pendidikan yang responsif terhadap perubahan serta tuntutan eksternalnya. Bagi para pakar manajemen pendidikan, hasil penelitian ini dijadikan 
sebagai bahan masukan untuk membantu para kepala sekolah dan para guru-guru dalam upaya meningkatkan keterampilan manajerial kepala sekolah, memperbaiki iklim organisasi sekolah dan peningkatan etos kerja kepala sekolah secara maksimal.

\section{Pustaka Acuan}

Anwar, Muh. Idochi. 2003. Hubungan antara Iklim Organisasi dengan Kepuasan Kerja dan Performansi Guru SMEA di Bandung : PPS IKIP Bandung.

Bass, Bernard. M. 1999. Leadership and Performance Beyond Expectations. New York: Free Press.

Bass. J, Avolio and Howell, J.M., 1985. Transformational Leadership, Transactional Leadership, Locus of Control, and Support for Innovation: Key Predictors of Consolidated-Business-Unit Performance. Journal of Applied Psychology, 78

Burns, J.M. and Aviolo. 1978. Charisma and Leadership in Organization. London: Sage.

Boyatzis. R.E 1982. The Competent Manager. Wiley : Chichester.

Burhanuddin 2004. Analisis Administrasi,Manajemen dan Kepemimpinan Pendidikan. Jakarta : Bumi Aksara.

Covey, Steven. 1992. Principle Centered Leadership. New York: Simon \& Shuster.

Delp, Dunphy and Stace, 1977. Under New Management. Reseville: Mc Graw-Hill.

Dunphy and Stace 1990. Under New Management. Reseville: Mc Graw-Hill.

Duncon. D.R 1972. "What is the Difference between Organizational Culture and Organization Climate? A native's point of view on a decade of paradigm wars". Academy of Management Review, July $p$ 619.

Gaffar, M. F. 2005. Perencanaan Pendidikan: Teori dan Metodologi. Jakarta: P2LPTK Depdikbud.

Ghozali, Imam 2005.Aplikasi Analisis Multivariat dengan Program SPSS. Semarang : Universitas Diponegoro.

Ghozali, Imam dan Fuad. 2005. Structural Equation Modeling: Teori, Konsep dan Aplikasi dengan Program Lisrel 8,54. Semarang: Universitas Diponegoro.

Good Carter, V 1973. Dictionary of Education. third edition. New York: MC Graw-Hill Book Company. Hunt, J.G. 1991. Leadership: A New Synthesis. CA: Sage.

Joreskog, K \& Sorbon, D.2001. The Student Edition of LISREL 8.51 for Windows (Computer Software) Lincolnwood,IL:Scientific Software International, Inc

Kartono, Tri Jaka.2006. Perencanaan Optimalisasi Peran Guru SMKN Teknologi didasarkan Faktor-faktor Determinasi Kinerja. Disertasi. Semarang :Universitas Negeri Semarang.

Locke, Edwin A and Associates. 1997. Esensi Kepemimpinan: Empat Kunci untuk Memimpin dengan Penuh Keberhasilan. Jakarta : Spektrum.

Mulyasa, Edward 2002 Manajemen Berbasis Sekolah. Bandung : PT Remaja Rusdakarya

Nurhadi, Mulyani A.2003. Pokok-pokok Pikiran Mengenai Pengelolaan Bidang Pendidikan dan Kebudayaan dalam rangka Pelaksanaan Undang-Undang RI No 22 Jakarta: Makalah Seminar

Jalal, Fasli dan Dedi, S. 2008. Reformasi Pendidikan dalam Konteks Otonomi Daerah. Jakarta: Adicita. Krajewsky, J Robert. 1983. The Elementary School Principalship. New York : Holt, Rinehart and Winston. Pinnes.S. Goodman. Dan Pennings, J.M. 1992. New Perspective on Organizational Effectiveness. San Francisco : Jossey-Bass

Peraturan Pemerintah. RI No 131997 tentang Standart Kepala Sekolah /Madrasah Jakarta: Sinar Grafika.

Peters, Robin, Steven 1992. Organizational Behavior: Concets, Controversies, Applications, 8th edition, CD-ROM version Prentice Hall.

Sanusi, A. 2001. Pendidikan Alternatif. Menyentuh Arus Dasar Persoalan Pendidikan dan Kemasyarakatan. Bandung: PPs IKIP dan Grafindo Media Pratama.

Siagian, Harbangan. 2006. Administrasi Pendidikan Suatu Pendekatan Sistemik. Salatiga: Satyawacana 
Sergiovanni,T.j.1987.The Principalship. A Reflective Practice Perspective. Boston: Allyn and Bacon,Inc Spencer, Lyle M., Jr dan Signe M Spencer. 1993. Competence at work, Models for Superior Performence. John Willey \& Sons.Inc.

Steers, Richard M 1977. Organizational Effectiveness, A Behavioral View. Santa Monica California: Goodyear Publishing Company Inc

Sinamo Jansen. 1999. Menciptakan Visi Motivatif (in Search of Powerfull Vision) Majalah Manajemen No 120 Agustus : 9

Sillin, H. 1994. The Relationship between Transformational and Transactional Leadership and School Improvement Outcomes. School Effectiveness and School Improvement, 5(3), 272-298.

Sergiovanni,T.J.1990.The Principalship. A Reflective Practice Perspective. Boston: Allyn and Bacon,Inc Tjiptono, Fandy dan Dianan A. 2006. Total Quality Management Yogyakarta: Andi

Wahjo Sumidjo. 2006. Kepemimpinan Kepala Sekolah. Tinjauan teoritik dan Permasalahnnya. Jakarta : Raja Grafindo Persada 